\title{
MORE ABOUT THE 'CROWN COMPETITION FACTOR'
}

\author{
By P. E. Vezina ${ }^{2}$
}

\begin{abstract}
The relationship between crown width and tree diameter is presented for open-grown pine in Quebec so that "Maximum Crown Area" in square feet can be estimated from tree diameter. The relationship between maximum crown area and tree diameter provides a basis for computing the "Crown Competition Factor" value of a stand as a measure of stand density. The CCF values for plots covering a range of ages were investigated.
\end{abstract}

\section{SOMMAIRE}

L'auteur étudie la relation qui existe entre la largeur de la cime et le d.h.p. du pin gris du Québec croissant à découvert; au moyen d'une équation établie par la méthode des moindres carrés, il expose que l'on peut estimer la "surface maximum de la cime", en pieds carrés, selon le diamètre de l'arbre. La relation établie entre la surface maximum de la cime et le diamètre de l'arbre constitue un élément de base pour calculer la valeur du "Facteur de concurrence de la cime" (FCC) dans un peuplement, comme mesure de densité de ce peuplement. L'on a cherché les valeurs du FCC dans des places d'étude contenant des arbres d'âges variés.

\section{INTRODUCTION}

The Crown Competition Factor (CCF), an expression of stand density which was developed by Krajicek, Brinkman, and Gingrich (1961), is useful to foresters who are concerned with the study of the comparative value of different parameters of stand density, the establishment of relationships between density and growth, or the development of new thinning and release cutting schedules. In order to apply the new measure of density, equations for estimating crown width of open-grown trees need to be developed. Such equations for free growing trees were given by Krajicek et al. (1961) for hickory (Carya ovata (Mill.) K. Kock), oak (Quercus alba L., Q. velutina Lam., $Q$. rubra L.), and Norway spruce (Picea abies (L.) Karst.), and by Vézina (1962) for balsam fir (Abies balsamea (L.) Mill.) and white spruce (Picea glauca (Moench) Voss.)

This paper is concerned with the relation of crown width to diameter at breast height for open-grown jack pine (Pinus banksiana Lamb.) as a prerequisite for applying $\mathrm{CCF}$ to jack pine stands, and with the relation of CCF to age.

\footnotetext{
${ }^{1}$ Department of Forestry, Canada, Forest Research Branch Contribution No. 505.

2 Research Officer, Forest Research Laboratory, P.O. Box 35, Sillery, P.Q.
} 


\section{MetHods}

The least squares equation developed for estimating crown width of jack pine is based on 83 trees measured in the Portneuf River watershed some ten miles west of Forestville, in Saguenay County, Quebec. Crown width was determined to the nearest half-foot from measurements made in two opposite directions at the base of the crown. Similarly, diameter (o.b.) at breast height was taken as the mean of two measurements at right angles on the tree. Other specifications were similar to those used by Vézina (1962).

\section{Relation Of Crown Width To Tree Diameter}

In a linear regression analysis, average crown width (CW) in feet was used as the dependent variable and diameter breast high (D) in inches as the independent variable. The correlation between the variables was highly significant $(r=0.960)$ and the regression for estimating crown width from tree diameter is:

(1) $\mathrm{CW}=2.036 \mathrm{D}+1.763$

Throughout the range of the sample data, a 1-per cent increase in tree diameter is accompanied by a 2.04-per cent increase in crown width. The standard error of estimate for this equation is 1.949 feet.

Figure 1 shows the relation between crown width and tree diameter. The two 95-per cent confidence bands indicate the limits of the range of population crown width and individual tree crown width for any given tree diameter.

The relation between crown width and tree diameter applies specifically to open-grown jack pine growing on poor sandy, fluvio-glacial soil in the boreal forest region (Rowe 1959). Because variable environmental conditions affect tree development differently, another relation may hold for trees growing in a different environment.

Significance of differences in the correlation coefficient ( $r$, the regression coefficient (byx), and the height (kyx) of regression was tested for white spruce and jack pine, and for balsam fir and jack pine (see Vézina 1962). The regression coefficients and the heights of the sample regressions were in both cases significant at the one per cent level. The differences in the correlation coefficients for the two sets of data, however, were not significant.

\section{Estimating CCF Of A Jack Pine Stand}

The maximum area occupied by the crown of a jack pine tree of specified d.b.h. is:

$\mathrm{MCA}=\frac{\frac{\pi}{(\mathrm{CW})^{2}}}{435.60}=0.0018(\mathrm{CW})^{2}$

Where MCA="maximum crown area" value of a jack pine with a crown diameter $\mathrm{CW}$

From the regression analysis of the jack pine data

(1) $\mathrm{CW}=2.036 \mathrm{D}+1.763$

and

$(C W)^{2}=4.145 D^{2}+7.178 D+3.108$

then

$\mathrm{MCA}=0.0075 \mathrm{D}^{2}+0.0129 \mathrm{D}+0.0056$ 


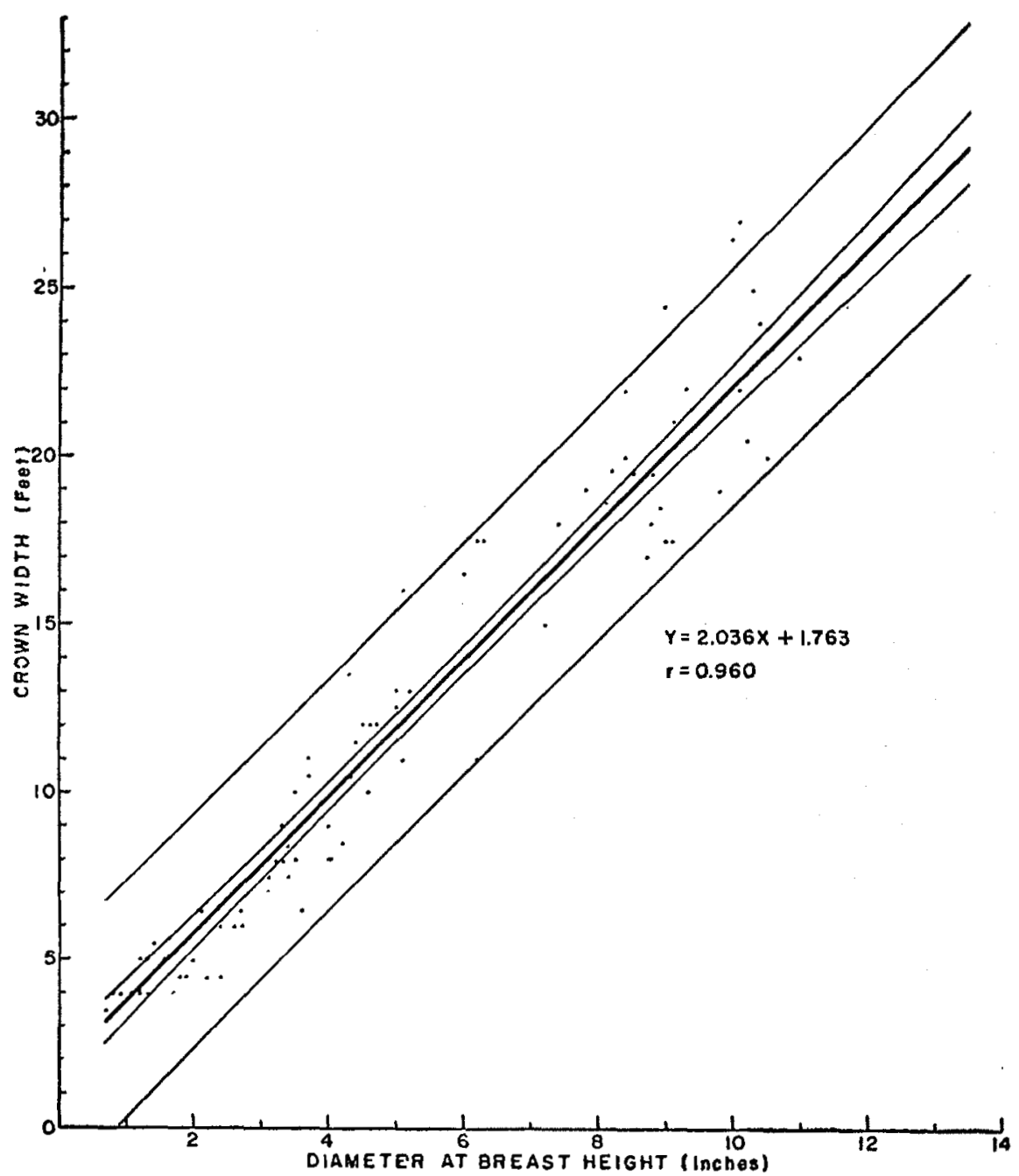

FIGURE 1. Regression of crown width on d.b.h., and 95 per cent confidence bands for crown width of population (narrow band) and of individual tree (wide band) of given d.b.h.

CCF value for a jack pine stand can be estimated from a stand table by accumulating the MCA values of the trees comprising the stand as determined from Equation 1.

The formula of CCF values for jack pine stands is therefore: $C C F=\frac{1}{A}\left[0.0075\left(\Sigma D_{1}^{2} N_{1}\right)+0.0129\left(\Sigma D_{1} N_{1}\right)+0.0056\left(\Sigma N_{1}\right)\right]$

Where

$\mathrm{Di}=$ Individual d.b.h. or d.b.h. class; 
$\mathrm{N}_{1}=$ Number of trees in d.b.h. class;

$\mathrm{A}=$ Area in acres.

Relation of CCF to Age of Stand

Spurr (1952) and Bickford et al. (1957) suggested that the ideal measure of density should be largely unrelated to the character and age of the stand and the quality of the site. To test how CCF would perform, analysis was made of 41 study plots representing a wide range of stocking - 50 to 130 square feet of basal area in 20- to 70-year-old even-aged stands of jack pine growing on poor sandy soils in Quebec. Possible dependence on age of CCF was investigated by means of a scatter diagram (Figure 2). CCF was plotted over each age and the trend of mean CCF values observed.

In general, CCF did not appear to be related to age, but this needs confirmation by similar additional tests.

The CCF values for jack pine stands had the tendency to approach an average CCF of 150 to 160 as age increased. However, differences in the range of CCF values in relation to age were evident. Within the lower age classes there was a wide spread of CCF values. This was reflected in the canopy density measurements made by the "moosehorn", which varied within the wide limits of 35 and 85 per cent.

Owing to the very small range in the site indices, the relation of CCF to site could not be analyzed.

\section{CONCLUSION}

According to the equation developed, crown width will increase 2.04 feet with each increase of one inch in d.b.h. This relation is significantly different from those found previously for balsam fir and white spruce. Open-grown jack pine have wider crowns than either fir or spruce at any given diameter. Hence, the minimum number of open-grown jack pine of specified d.b.h on an acre that could produce a full crown closure will be less than that of fir or spruce. It is worthwhile to note that, because of its wider crown, jack pine stands with good stocking also produce fewer trees per acre than do stands of either fir or spruce of the same average diameter or the same age and site index, as measured by height and age (Kabzems and Kirby 1956, Kirby 1962). This is, to a considerable extent, a reflection of differences in tolerance.

\section{REFERENCES}

BICKFORD, C. A. et al. 1957. Stocking, normality, and measurements of stand density. J. For. 55: 99-104.

KABZEMS, A., and C. L. KIRBY. 1956. The growth and yield of jack pine in Saskatchewan. Saskatchewan Dept. of Natural Resources. Forestry Branch, Tech. Bull. No. 2. 66 pp.

KIRBY, C.L. 1962. The growth and yeild of white spruce-aspen stands in Saskatchewan. Saskatchewan Dept. of Natural Resources, Forestry Branch, Tech. Bull. No. 4. 58 pp.

KRAJICEK, J. E., BRINKMAN, K. A. and S. F. GINGRICH. 1961. Crown competition A measure of density. For. Sci. 7: 35-42.

ROWE, J. S. 1959. Forest regions of Canada. Canada, Dept. North Aff. and Nat. Res., Bull. No. 123.

SPURR, S.H. 1952. Forest inventory. Ronald Press, New York.

VEZINA, P. E. 1962. Crown width-d.b.h. relationships for open-grown balsam fir and white spruce in Quebec. For. Chron. 38 4:463-73. 


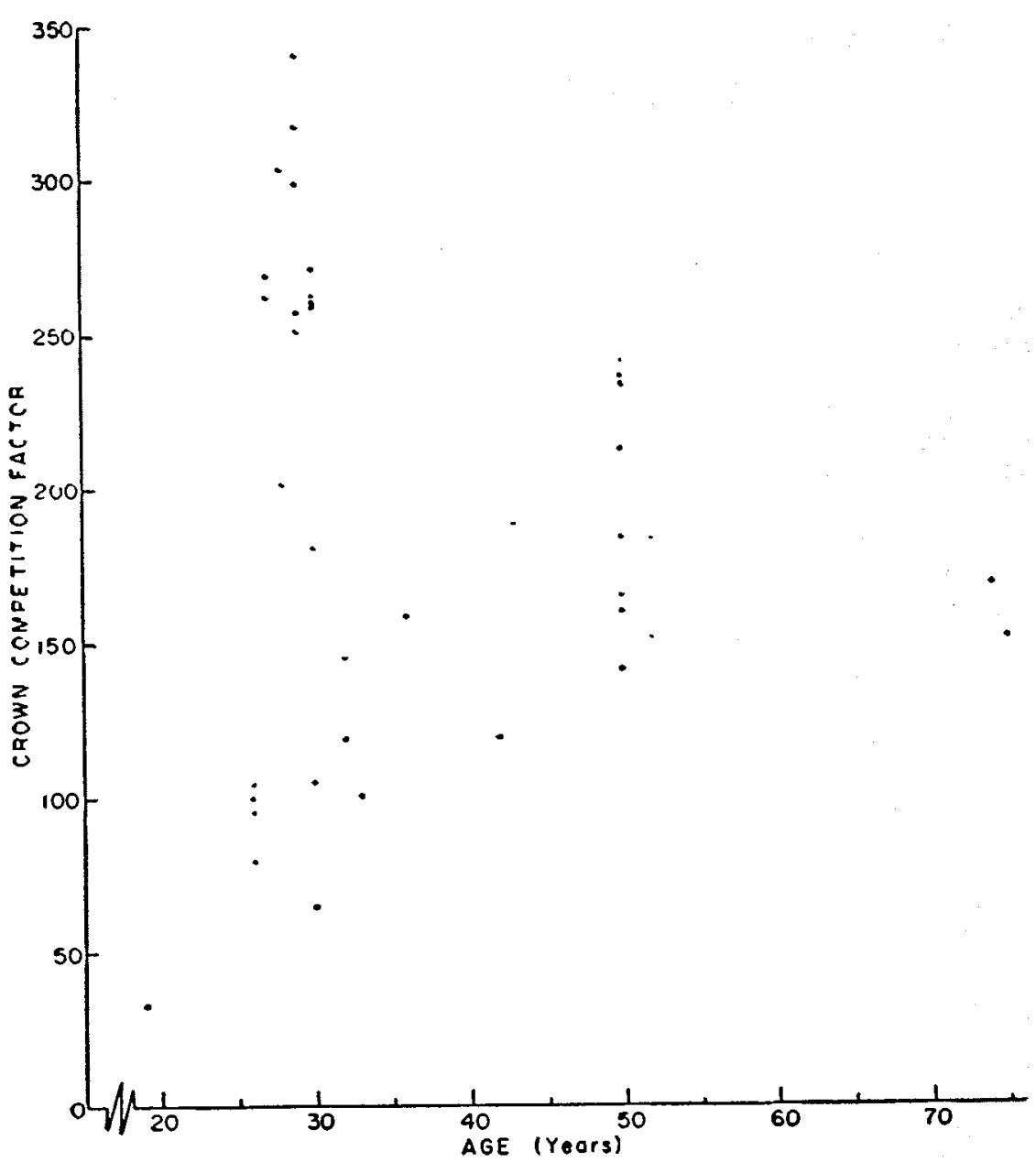

FIGURE 2. Scatter diagram relating CCF to age of jack pine stands. 